\title{
Status of nesting loggerhead turtles Caretta caretta at Bald Head Island (North Carolina, USA) after 24 years of intensive monitoring and conservation
}

\author{
Lucy A. Hawkes, Annette C. Broderick, Matthew H. Godfrey and Brendan J. Godley
}

\begin{abstract}
A 24-year set of data from monitoring of a nesting beach at Bald Head Island, North Carolina, USA, was analysed in parallel with limited data from nearby rookeries to investigate trends in loggerhead turtle Caretta caretta nesting numbers. There was no statistical evidence of an increasing or decreasing trend in numbers of clutches laid per year, although a significant decrease in the number of turtles nesting and number of clutches laid per year was found from 1991. Remigrating turtles
\end{abstract}

were larger and had larger annual clutch frequencies than neophyte turtles. Annual levels of nesting at beaches within the Cape Fear area were significantly correlated. The stable trend in number of clutches laid across more than two decades is discussed in relation to other factors affecting marine turtles in North American waters.

Keywords Bald Head Island, Caretta caretta, loggerhead turtle, monitoring, nesting, USA.

\section{Introduction}

The largest nesting population of the loggerhead sea turtle Caretta caretta in the Atlantic Ocean is that of the south-eastern USA where an estimated 74,000 nests are laid annually (Turtle Expert Working Group, 2000). Loggerhead nesting was first reported in the USA by Catesby (1731-1743) and currently occurs as far north as New Jersey and 2,200 km southwards to the Caribbean (Carr et al., 1979; Shoop et al., 1985). Aerial surveys flown by Murphy \& Hopkins (1984) indicated that approximately $90 \%$ of the nesting effort in the USA occurs in Florida, with a further 6\% in South Carolina and 2\% in each of Georgia and North Carolina. The loggerhead population in the south-eastern USA is genetically structured into three subpopulations (Encalada et al., 1998): north-west Florida (the panhandle subpopulation), south Florida (the southern subpopulation), and north-eastern Florida to North Carolina (the northern subpopulation).

Threats to sea turtles in the marine environment of North America come from diverse fishing operations (including extensive trawling and gill netting), dredging, pollution, power-plant entrapment, entanglement and

Lucy A. Hawkes* (Corresponding author), Annette C. Broderick and Brendan J. Godley Marine Turtle Research Group, Centre for Ecology and Conservation, University of Exeter in Cornwall, Tremough Campus, Penryn, TR10 9EZ, UK. E-mail lhawkes@seaturtle.org

Matthew H. Godfrey North Carolina Wildlife Resources Commission, 1507 Ann Street, Beaufort, NC 28516, USA.

*Also at: Bald Head Island Conservancy, PO Box 3109, Bald Head Island, NC 28461-7000, USA.

Received 9 February 2004. Revision requested 8 June 2004 Accepted 12 August 2004 marina and dock development (NMFS \& FWS, 1991). Turtles on the beaches of North Carolina may be affected by beach renourishment, artificial lighting and increased human presence (e.g. development or beach driving). Specific rookeries of the northern subpopulation have been characterized as in decline, particularly in Georgia and South Carolina (Frazer, 1986; Hopkins-Murphy \& Murphy, 1988; National Research Council, 1990; NMFS \& FWS, 1995; Turtle Expert Working Group, 2000). Hopkins-Murphy et al. (2001) reported a 5\% decline per year in the nesting population of South Carolina from 1980-1997. Nesting at Little Cumberland Island, Georgia, was also reported to be declining by $2.6 \%$ per annum between 1964 and 1995 (Frazer, 1983; Turtle Expert Working Group, 1998). Because of its small and therefore vulnerable size, the northern subpopulation has been of special concern. In January 2002 the Turtle Island Restoration Network filed a petition (Turtle Island Restoration Network, 2002) to reclassify the Florida panhandle and northern subpopulations of Atlantic loggerhead turtles as distinct and endangered. Federal agencies recently ruled that this reclassification was not warranted (FWS \& NMFS, 2003). To date, few data have been published concerning trends of nesting populations of loggerhead turtles in North Carolina.

Prompted by local concern and perception of a general decline, this study was initiated to analyse detailed biological data from a 24-year monitoring project of loggerhead turtles at Bald Head Island, North Carolina, USA.

\section{Methods}

The study was carried out at Bald Head Island, located in south-eastern North Carolina at Cape Fear (Fig. 1). The 


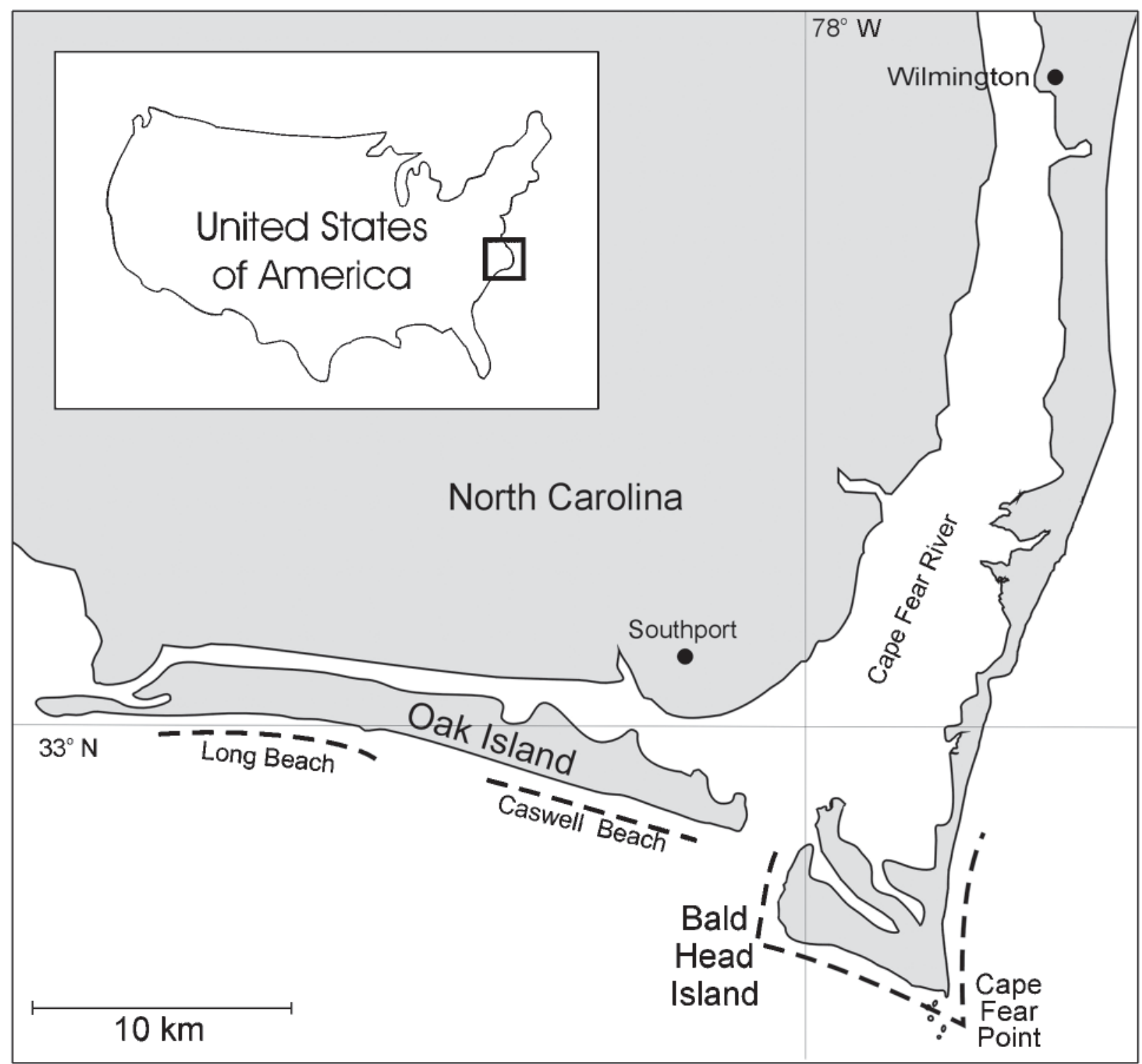

Fig. 1 Map of the Cape Fear region of south-eastern North Carolina, USA, showing Bald Head Island, Caswell Beach and Long Beach, Oak Island. Broken line represents beaches patrolled for monitoring efforts at the different sites. Inset shows position of main figure within the USA.

coast of the Island has extensive sandy shores and $15.3 \mathrm{~km}$ of beaches. The beaches were patrolled every hour on a nightly basis between 21.00 and 06.00 , from late May until mid August 1980 to 2003, by teams on all terrain vehicles.

Tagging was initiated in 1991. If turtles carried flipper tags and had been recorded nesting in a previous season, they were recorded as remigrants. Turtles that carried no flipper tags were recorded as neophytes (turtles recorded nesting for the first time) and Inconel flipper tags (National Band and Tag Co.) were applied to the trailing edges of both front flippers. For the purpose of this investigation neophytes were only considered as such from the 1993 season onwards. In the 2002 and 2003 nesting seasons only, nesting turtles were also injected with PIT tags. We collected data on curved carapace length (notch to tip) and width as described by Bolten (1999). The morphometric data used in analyses used the mean of all measurements of each female per season.

All adult female emergences were recorded as either nests (when a clutch was deposited) or non-nesting emergences (no egg deposition). The rate of interception of turtles was measured as the proportion of nests that were observed and attributed to a given turtle. If activities were unobserved, tracks were examined for evidence of clutch deposition, following Schroeder \& Murphy (1999). Adult emergence success was calculated as the proportion of emergences that resulted in clutch 
deposition out of the total number of nesting attempts (nests plus non-nesting emergences). Nests were identified and protected from predation using wide mesh wire screens in all study years. Nests were transplanted if they were likely to experience tidal inundation, or if they were laid in an area of high pedestrian traffic. Nest hatch success was the number of clutches that produced viable hatchlings out of the total clutches laid that season. Nests were excavated 3 days after completion of hatchling emergence or at 70 days of incubation, and contents counted to establish hatchling emergence success, defined as the proportion of eggs that produced viable hatchlings that reached the beach surface (Miller, 1999; $\mathrm{HE} / \mathrm{T}$ where $\mathrm{HE}=$ number of hatched eggs minus dead hatchlings and live subterranean hatchlings and $\mathrm{T}=$ total number of eggs in the nest).

The level of interannual variability in the number of nests laid was quantified using the coefficient of variation (CV) following Broderick et al. (2001). Observed clutch frequency $(\mathrm{OCF})$ was the number of clutches attributed to each known female. However, some turtles re-nested after intervals corresponding to multiple internesting intervals, (modal interval 14 days in this study) suggesting they had laid unobserved clutches during this interval. Therefore we adjusted OCF values to calculate estimated clutch frequency (ECF; Broderick et al., 2002) and give those values herein.

\section{Results}

Nesting at Bald Head Island during 1980-2003 ranged from 51 to 196 nests per season (mean $\pm \mathrm{SD}=108 \pm 37.8$, $\mathrm{CV}=0.35$; Fig. 2a) but showed no significant overall trend over time (Regression: $F_{1,23}=4.122, \mathrm{P}>0.05$, $\left.R^{2}=0.158\right)$. However, the magnitude of nesting at Bald Head Island declined significantly if data since 1991, when tagging began, were considered (Regression: $\left.F_{1,12}=8.55, \mathrm{P}<0.05, R^{2}=0.437\right)$. Tagging data were used to estimate the total annual number of turtles nesting in each season (mean $\pm \mathrm{SD}=39.2 \pm 13.6$, range 23-70) from 1991-2003. There was a significant negative trend in the total number of turtles recorded nesting since $1991\left(F_{1,12}=16.16, \mathrm{P}<0.05, R^{2}=0.595\right.$; Fig. $\left.2 b\right)$. Neither nest hatch success (mean $\pm \mathrm{SD}=65.7 \pm 21.2 \%$, range 63.1-90.6\%; Fig. 3a) nor hatchling emergence success $(82.9 \pm 20.7 \%$, range $63.1-90.6 \%$; Fig. $3 b)$ showed any significant trend over time. No trends in adult emergence success $(47.5 \pm 11.8 \%$, range $28.1-61.5 \%$; Fig. $3 c)$ were apparent.

During the study tagging period (1991-2003) 477 turtles were recorded, 110 of which were subsequently recorded as remigrants. The latter had remigration intervals between 1 and 7 years, although 93\% returned to nest between 2 and 4 years, and $85 \%$ returned after 3
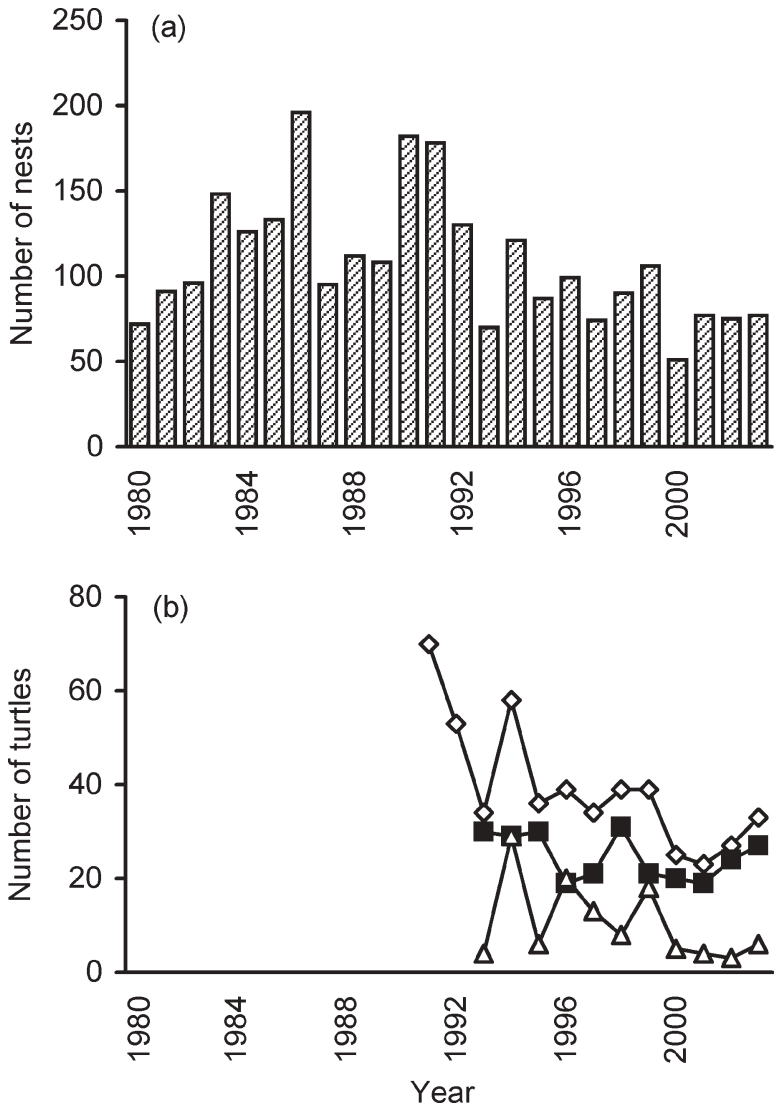

Fig. 2 (a) Number of loggerhead turtle nests recorded at Bald Head Island, 1980-2003, and (b) number of nesting turtles (diamonds) recorded at Bald Head Island each year from 1991-2003. Neophyte (squares) and remigrant turtles (triangles) are shown for 1993-2003. No tagged turtles re-nested in 1992.

years or less (Fig. 4). Mean rate of interception did not vary systematically (mean $\pm \mathrm{SD}=79.4 \pm 7.2 \%$, range $66.2-87.8 \%$ per season). Remigrant turtles (mean $\pm \mathrm{SD}=104.2 \pm 1.8 \mathrm{~cm}, \mathrm{n}=99)$ were significantly larger than neophyte turtles $(99.7 \pm 1.4 \mathrm{~cm}, \mathrm{n}=299)$, (paired $t$-test $t_{10}=6.151, \mathrm{P}<0.01 ;$ Fig 5 ). Remigrants contributed a significantly larger number of clutches per year (median ECF (interquartile range) $=3.2(3-4.1)$ than neophytes (1.7 (1.6 - 1.97); Fig. 6; Mann Whitney U Test: $\left.W_{1,20}=0.00, \mathrm{P}<0.01\right)$. There was no demonstrable trend in either female size (Fig. 7) or clutch frequency (ECF, Fig. 6).

We could not clearly assess the level of within season nest site fidelity as there is no regular night-time monitoring on nearby beaches: Caswell Beach (c. $3 \mathrm{~km}$ away) and Long Beach, Oak Island (c. $7 \mathrm{~km}$ away; Fig. 1). Nests at these two sites show interannual variation (Caswell Beach, mean annual total $=57.6$, range $19-100$ nests, $\mathrm{CV}=0.4$, Fig. 8a; Long Beach, mean annual total $=63.3$, range 27-104 nests, $C V=0.4$, Fig. $8 \mathrm{~b}$ ) but no sign of the downward trend suggested in recent years at Bald Head 

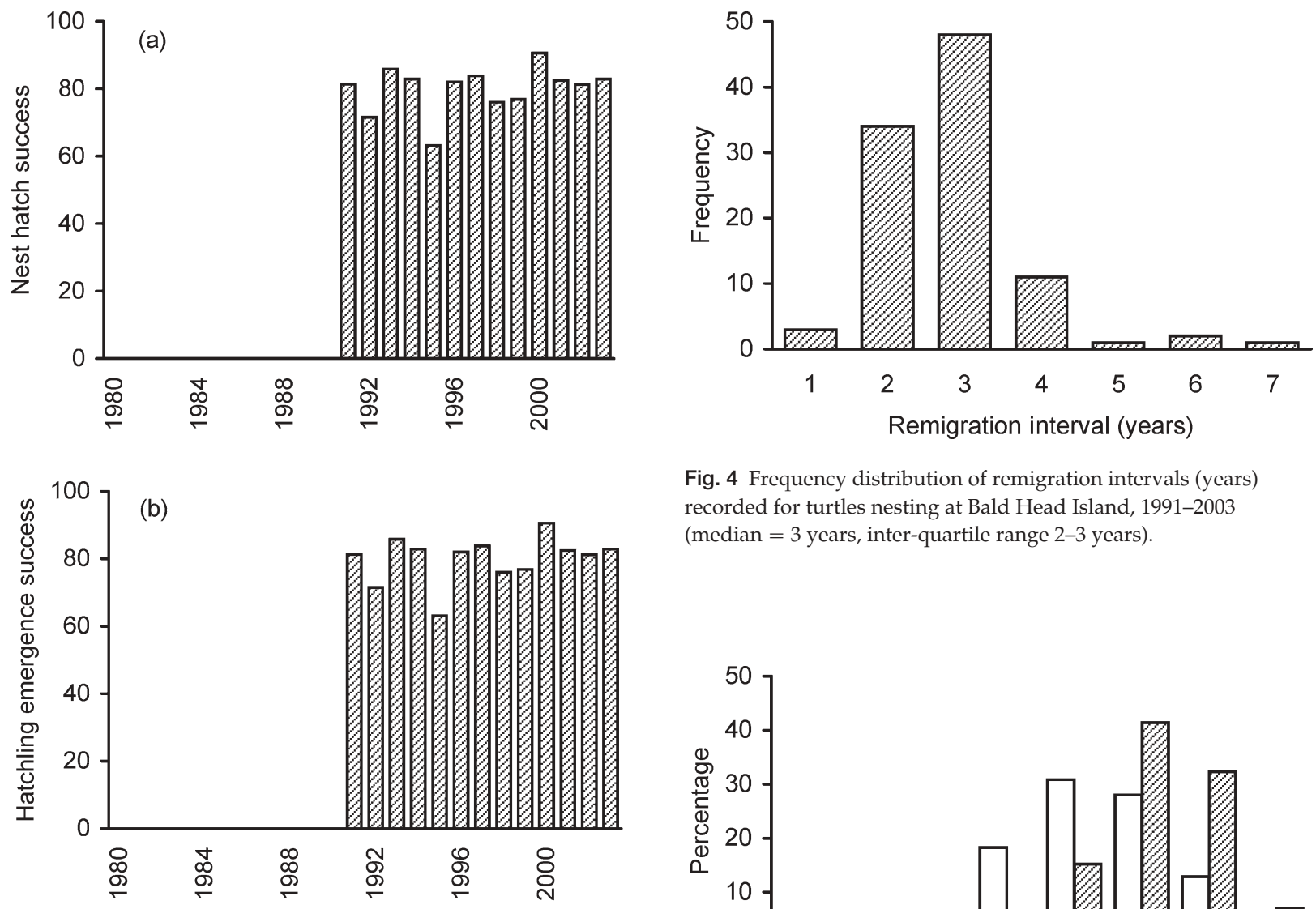

Fig. 4 Frequency distribution of remigration intervals (years) recorded for turtles nesting at Bald Head Island, 1991-2003 (median $=3$ years, inter-quartile range $2-3$ years).

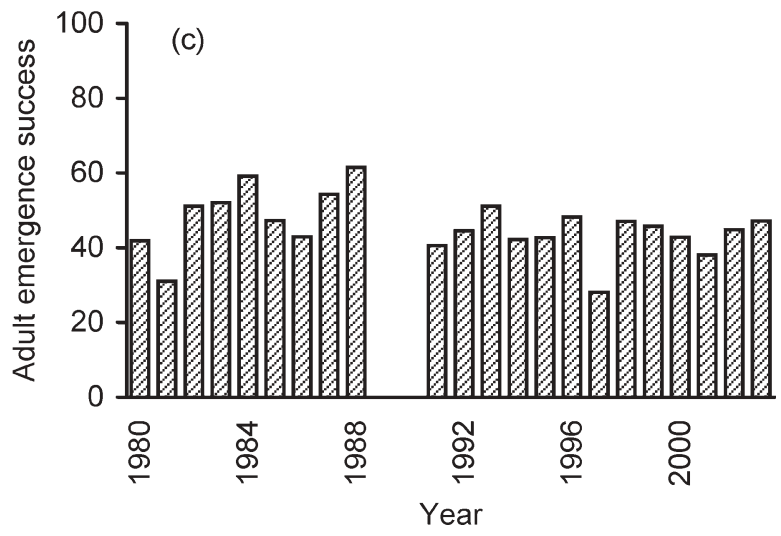

Fig. 3 Distributions of (a) nest hatch success, (b) mean hatchling emergence success, and (c) adult emergence success (see Methods for definitions). Data are not available for adult emergence success for 1989 and 1990.

Island (Fig. 2). The seasonal totals of nests at all three beaches are significantly correlated with one another (Spearmans Rank: Bald Head vs Caswell Beach: $r=0.598$, Bald Head vs Long Beach: $r=0.474$, Caswell vs Long Beach: $r=0.867 ; \mathrm{P}<0.05)$. When annual nest totals from all three beaches were pooled for the period 1989-2003 (mean $\pm \mathrm{SD}=226.5 \pm 72.03, \quad \mathrm{CV}=0.38$; Fig. 8c), there was no significant trend over time.

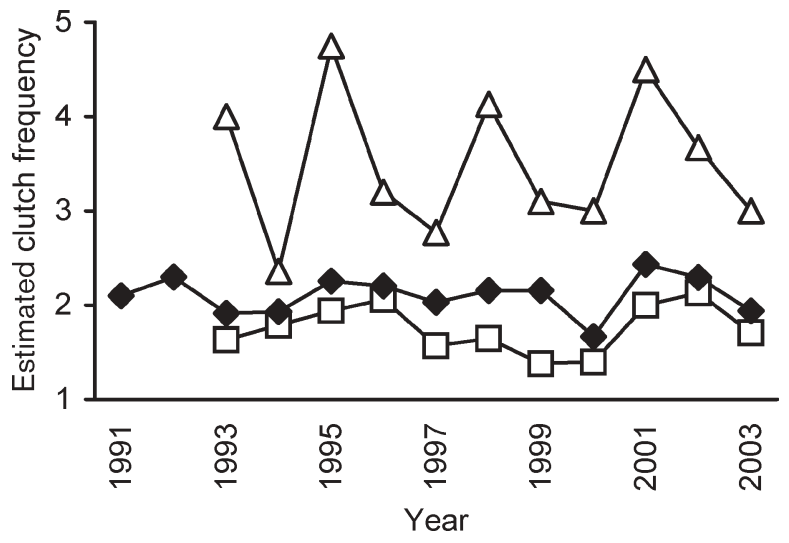

Fig. 6 Mean estimated clutch frequency for all turtles (diamonds), neophytes (squares) and remigrants (triangles) 1991-2003. 


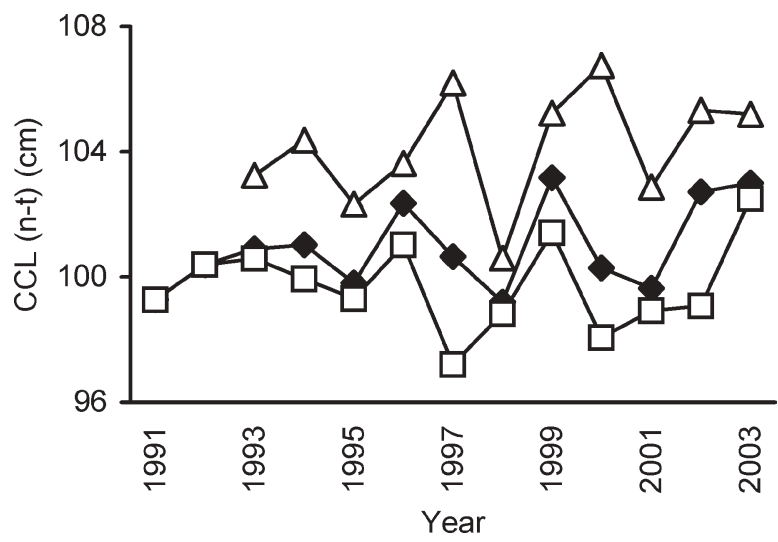

Fig. 7 Mean annual curved carapace lengths (CCL(n-t)) of all turtles (diamonds), neophytes (squares) and remigrants (triangles) 1991-2003.
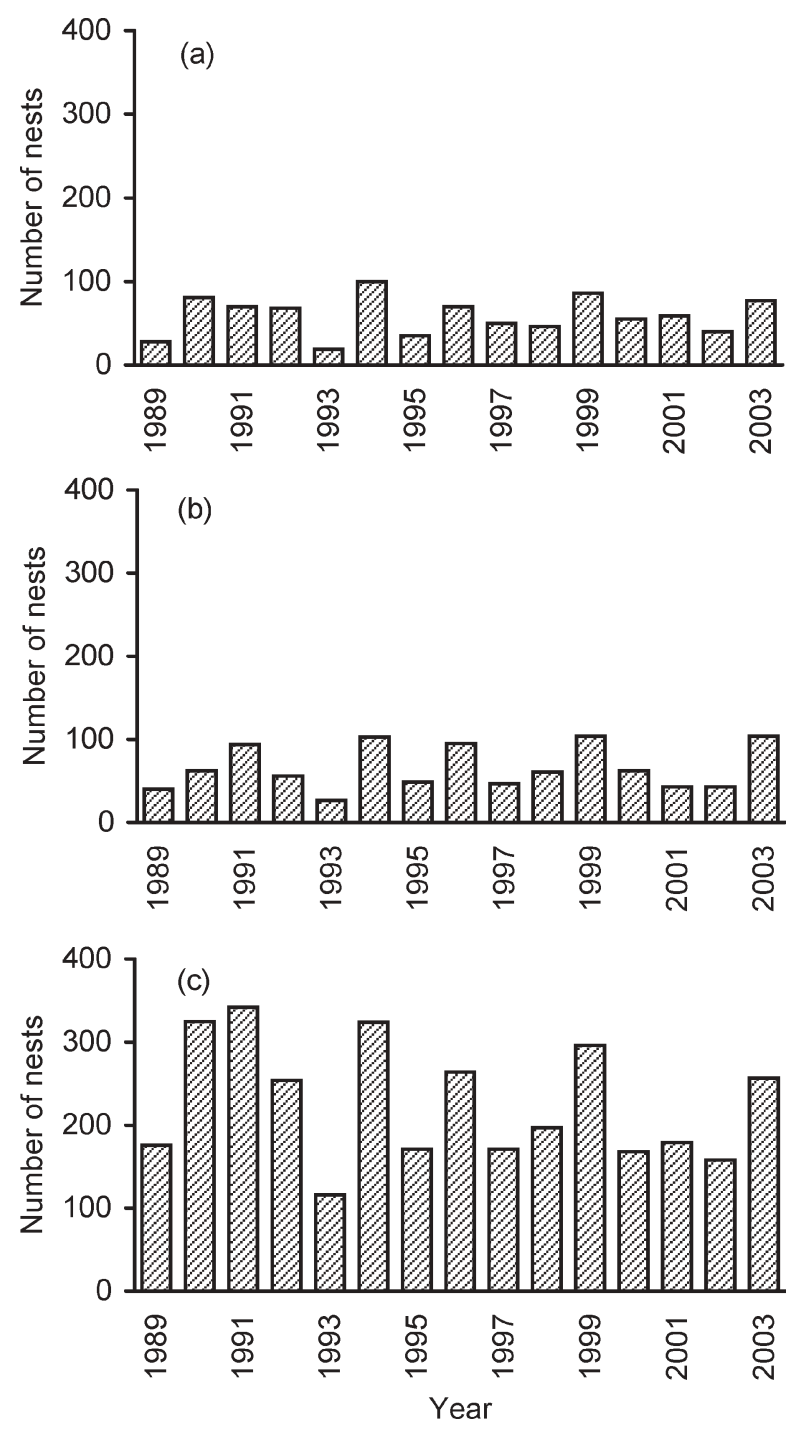

Fig. 8 Number of loggerhead turtle nests recorded at (a) Caswell Beach, Oak Island, (b) Long Beach, Oak Island, North Carolina, USA, and (c) throughout the Cape Fear region (Bald Head Island, Caswell Beach and Long Beach, Oak Island combined) 1991-2003.

\section{Discussion}

Although current nesting numbers are lower than the early 1990s, for the whole period (1980-2003) we found no evidence of a decline in numbers across the Cape Fear region. Nesting at Bald Head Island is relatively stable with fluctuations among years at the higher end of the range $(\mathrm{CV}=0.12-0.45)$ of the conspecific populations reviewed by Broderick et al. (2001). No measured factors reflecting beach suitability (such as adult emergence success) gave any indication of deterioration in the quality of Bald Head Island as a breeding site.

The results of this long-term effort offer four lessons regarding marine turtle monitoring and the interpretation of the data:

Firstly, it is important to consider the duration of monitoring effort. The 24-year data-set in its entirety suggests that the nesting population in the Cape Fear region is stable. However, if we only considered the data collected at Bald Head Island since the start of tagging in 1991 we would be concerned about a significant decline in nesting numbers. This highlights the critical need for monitoring of index sites over long periods and demonstrates that long-term monitoring is crucial in making robust conclusions about population trends.

Secondly, it is important to consider the geographic range of monitoring effort. Loggerhead turtles do not always show high levels of nest site fidelity (LeBuff, 1990). Eleven turtles originally tagged at Bald Head Island have been reported nesting elsewhere on the Atlantic coast of the USA (North Carolina $n=6$, South Carolina $\mathrm{n}=2$, Georgia $\mathrm{n}=2$, Florida $\mathrm{n}=1$; Peter Eliazar, pers. comm.). There will undoubtedly be some exchange of turtles with other local beaches within and between seasons. When the data from Caswell Beach and Long Beach were added to the Bald Head Island data, the impression of population stability was greatly strengthened. Given that the annual nesting totals of these beaches are significantly correlated it is likely that these turtles are part of the same stock, subject to similar environmental influences at the foraging grounds, which in turn contribute to synchrony in reproductive cycles as demonstrated in regional green turtle populations (Limpus \& Nicholls, 1988; Kasperek et al., 2001).

Thirdly, at best, successful conservation efforts will take several more decades to yield detectable results on the nesting beaches. Despite 24 years of protection and monitoring and a wide range of State and Federal regulations, including the introduction and mandatory use of Turtle Excluder Devices to all trawling vessels in US waters in 1992, the regulation of certain fisheries (Julian \& Beeson, 1998), and other measures designed to reduce the impact of anthropogenic activities, there has been no increase in nesting numbers in the Cape Fear region. 
There are several factors that may effectively limit population increase. Recent skeletochronological analyses suggest that loggerhead turtles in the north-west Atlantic mature in c. 30 years (Snover, 2002). As such, monitoring at Bald Head Island may not have been in place long enough to detect positive impacts. A similar steady trend in annual nest numbers of loggerhead turtles has been reported from a nesting beach in Bahia, Brazil, which also initiated a nest protection programme in 1980 (Santos et al., 2000). Sexual differentiation of loggerhead turtles is influenced by incubation temperatures experienced by clutches (Yntema \& Mrosvosky, 1980). On south-east USA beaches, at the cooler northern end of the nesting range, loggerhead turtles tend to produce more male hatchlings than in Florida (Mrosovsky \& Provancha, 1992). It is likely that nesting numbers will increase more quickly for a nesting population that produces proportionally more female hatchlings. Therefore, it may not be surprising that some nesting beaches in Florida are showing signs of increases in numbers of nests laid (Bagley et al., 2000) while North Carolina nesting beaches show no increase. There may be other factors outside the nesting area affecting the survivorship of this reproductive population. From 1993 to 2002, on average 437 turtles per year (up to five species) were stranded dead in North Carolina (M. Godfrey, unpubl. data). It is estimated that the number of observed stranded turtles represents $7-13 \%$ of all mortalities in an area (Epperly et al., 1996), which equates to 3,362-6,243 turtle mortalities in North Carolina waters per year, $60-80 \%$ of which are loggerhead turtles (Cluse \& Godfrey, in press). Although the sources of these turtles include nesting beaches throughout the south-eastern USA (Bass et al., 1998) it is possible that the smaller nesting population in North Carolina is more sensitive to the anthropogenic effects of these increased mortalities from strandings.

Fourthly, other parameters in addition to nest numbers and number of turtles should form part of ongoing monitoring efforts. In this study, remigrants were larger and contributed more clutches per year than neophytes. This could be the result of either stronger within season site fidelity, greater reproductive capacity for remigrants or some combination of both of these factors. This relationship has also been found in loggerhead turtles in Georgia (Frazer \& Richardson, 1984), and in the Mediterranean (Hays \& Speakman, 1992; Broderick et al., 2003), suggesting that trends in mean female size and clutch frequency may also be used to assess population status. A size index signalling population change in loggerhead turtles has recently been demonstrated in Japan (Hatase et al., 2002). Turtles at Bald Head Island exhibited overall higher estimated clutch frequency (mean $\pm \mathrm{SD}=$ $2.48 \pm 1.46$ ) than at some other rookeries (e.g. Northern Cyprus, $1.9 \pm 1.2$; Broderick et al., 2003), but were below the range of values reported from the south-east USA (2.81-4.18; Schroeder et al., 2003). Incomplete capture rates and 'edge effect' (Murphy \& Hopkins, 1984) will lower resultant estimated clutch frequencies. Our interception rate, however, was consistently high and did not vary systematically, suggesting that our estimates are likely to be sufficiently sound for comparison of nest frequencies over time.

There could have been some recent changes that made Bald Head Island less suitable for nesting, such as increased development, disturbance, beach front lighting or negative effects from the nearshore, heavily used Cape Fear shipping channel, causing individuals to switch to nearby sites, contributing to lowered adult emergence success or leading to fewer clutches per female. However, our data suggest that all these parameters are stable.

Since tagging began in 1991 there has been a significant decline in the annual number of nesting individuals and the number of nests laid. It must be considered that given the observed stability of the Cape Fear region as a whole (even since tagging began), turtles may have switched to other Cape Fear beaches after being disturbed by tagging. Broderick \& Godley (1999) found that tagging caused a small proportion of turtles to prematurely abandon nesting activity, but 5 out of the 9 turtles that reacted negatively returned to nest in the same season.

In summary, nesting beach surveys are the most commonly used methodology for assessing the status of marine turtle populations. Despite their logistical ease, even when study sites are relatively comprehensive, nesting beach surveys may not provide a sufficiently sensitive index of the status of the whole population. Firstly, they require many years to detect all but the steepest population trends. Secondly, they provide no direct information on adult males and cohorts of juveniles. It would be prudent in the future to investigate the relative abundance and population trends of these loggerhead turtles in their foraging grounds (see Bjorndal \& Bolten, 2000 , for a collection of reviews) to more accurately assess population status.

\section{Acknowledgements}

Many thanks to the interns and naturalists of the Bald Head Island Conservancy, with particular thanks to Billy Brooks and Heather Woodson for their help reconstructing the history of the sea turtle protection project, and to Brannon Quel and David Webster for database management. We are grateful to staff, trustees and supporters of the Bald Head Island Conservancy for their logistical support and hospitality. We also thank the dedicated volunteers of Caswell Beach and Oak Island for their tireless monitoring efforts. This project would not have 
been possible without the invaluable help and support over the years from the North Carolina Wildlife Resources Commission. The manuscript was greatly improved by comments from two anonymous referees. BJG/ACB are supported by the Natural Environment Research Council and the Foreign and Commonwealth Environment Fund for the Overseas Territories. Lucy Hawkes is part-funded by the Anning Morgan Bursary from the University of Exeter.

\section{References}

Bagley, D.A., Uong, L.T., Danner, A.B., Hirama, S., Wick, L.A. \& Ehrhart, L.M. (2000) Marine turtle nesting at the Archie Carr National Wildlife Refuge in 1997. In Proceedings of the Eighteenth International Sea Turtle Symposium on Sea Turtle Biology and Conservation (compilers F.A. Abreu-Grobois, R. Briseno-Duenas, R. Marquez \& L. Sarti), pp. 175-177. NOAA Technical Memorandum NMFS-SEFSC-436, US Department of Commerce, USA.

Bass, A.L., Epperly, S.P., Braun, J., Owens, D.W. \& Patterson, R.M. (1998) Natal origin and sex ratios of foraging sea turtles in the Pamlico-Albermarle estuarine complex. In Proceedings of the Seventeenth Annual Sea Turtle Symposium (compilers S.P. Epperly \& J. Braun), pp. 148-149. NOAA Technical Memorandum NMFS-SEFSC-415, US Department of Commerce, USA.

Bell, R. and Richardson, J.I. (1978) An analysis of tag recoveries from loggerhead sea turtles (Caretta caretta) nesting on Little Cumberland Island, Georgia. Florida Marine Research Publication, 33, 39-44.

Bjorndal, K.A. \& Balazs, G.H. (1983) Manual of Sea Turtle Research and Conservation Techniques. Center for Environmental Education, Washington, DC, USA.

Bjorndal, K.A. \& Bolten, A.B. (eds) (2000) Proceedings of A Workshop on Assessing Abundance and Trends for In-water Sea Turtle Populations. NOAA Technical Memorandum NMFS-SEFSC-445, US Department of Commerce, USA.

Bolten, A.B. (1999) Techniques for measuring sea turtles. In Research and Management Techniques for the Conservation of Sea Turtles (eds K.L. Eckert, K.A. Bjorndal, F.A. Abreu-Grobois \& M. Donnelly), pp. 110-114. IUCN/SSC Marine Turtle Specialist Group Publication No. 4, Washington, DC, USA.

Broderick, A.C., Glen, F., Godley, B.J. \& Hays, G.C. (2002) Estimating the number of green and loggerhead turtles nesting annually in the Mediterranean. Oryx, 36, 227-235.

Broderick, A.C., Glen, F., Godley, B.J. \& Hays, G.C. (2003) Variation in reproductive output of marine turtles. Journal of Experimental Marine Biology and Ecology, 288, 95-109.

Broderick, A.C. \& Godley, B.J. (1999) Effect of tagging marine turtles on nesting behaviour and reproductive success. Animal Behaviour, 58, 587-591.

Broderick, A.C., Godley, B.J. \& Hays, G.C. (2001) Trophic status drives interannual variability in nesting numbers of marine turtles. Proceedings of the Royal Society B, 268, 1481-1487.

Carr, A.F.J., Jackson, D.R. \& Iverson, J.B. (1979) Marine turtles. In A Summary and Analysis of Environmental Information on the Continental Shelf and Blake Plateau From Cape Hatteras to Cape Canaveral, Volume 1, Book 3 (ed. S. Gardiner), pp. 1-45. Center for Natural Areas, South Gardiner, USA.

Catesby, M. (1731-1743) The Natural History of Carolina, Florida and the Bahama Islands. C. Marsh, London, UK.
Cluse, W.M \& Godfrey, M.H. (in press) Recent trends in sea turtle strandings (1993-2002), North Carolina, USA. In Proceedings of the Twenty Third Annual Symposium on Sea Turtle Biology and Conservation (compilers S. Sadove, N.J. Pilcher \& K. Shanker). NOAA Technical Memorandum, US Department of Commerce, USA.

Encalada, S.E., Bjorndal, K.A., Bolten, A.B., Zurita, J.C., Schroeder, B., Possardt, E., Sears, C.J. \& Bowen, B.W. (1998) Population structure of loggerhead turtle (Caretta caretta) nesting colonies in the Atlantic and Mediterranean as inferred from mitochondrial DNA control region sequences. Marine Biology, 130, 567-575.

Epperly, S.P. (2003) Fisheries-related mortality and Turtle Excluder Devices (TEDs). In The Biology of Sea Turtles, Volume II (eds P.L. Lutz, J.A. Musick \& J. Wyneken), pp. 339-353. CRC Marine Biology Series, CRC Press, Boca Raton, USA.

Epperly, S.P., Braun, J., Chester, A.J., Cross, F.A., Merriner, J.V., Tester, P.A. \& Churchill, J.H. (1996) Beach strandings as an indicator of at-sea mortality of sea turtles. Bulletin of Marine Science, 59, 289-297.

Frazer, N.B. (1983) Survivorship of adult female loggerhead sea turtles, Caretta caretta, nesting on Little Cumberland Island, Georgia, USA. Herpetologica, 39, 436-447.

Frazer, N.B. (1986) Kemp's decline: special alarm or general concern? Marine Turtle Newsletter, 37, 5-7.

Frazer, N.B. \& Richardson, J.I. (1984) The relationship of clutch size and frequency to body size in loggerhead turtles, Caretta caretta. Journal of Herpetology, 20, 81-84.

FWS \& NMFS (Fish and Wildlife Service \& National Marine Fisheries Service) (2003) 12-month finding on a petition to list the Northern and Florida Panhandle loggerhead sea turtle (Caretta caretta) subpopulations as endangered. Federal Register, 68(178), 53947-53955, 15 September 2003.

Hatase, H., Goto, K., Sato, K., Bando, T., Matsuzawa, Y. \& Sakamoto, W. (2002) Using annual body size fluctuations to explore potential causes for the decline in a nesting population of the loggerhead turtle Caretta caretta at Senri beach, Japan. Marine Ecology Progress Series, 245, 299-304.

Hays, G.C. \& Speakman, J.R. (1992) Clutch size for Mediterranean loggerhead turtles (Caretta caretta). Journal of the Zoological Society of London, 226, 321-327.

Hopkins-Murphy, S.R. \& Murphy, T.M. (1988) Status of the loggerhead turtle in South Carolina. In The Eighth Annual Workshop on Sea Turtle Conservation and Biology (compiler B. Schroeder), pp. 35-37. NOAA Technical Memorandum NMFS-SEFSC-214, US Department of Commerce, USA.

Hopkins-Murphy, S.R., Murphy, T.M., Hope, C.P., Coker, J.W. \& Hoyle, M.E. (2001) Population Trends and Nesting Distribution of the Loggerhead Turtle (Caretta caretta) in South Carolina 1980-1997. Final Report to the US Fish and Wildlife Service. South Carolina Department of Natural Resources, Charleston, USA.

Julian, F. \& Beeson, M. (1998) Estimates of marine mammal, turtle and seabird mortality for two California gillnet fisheries: 1990-1995. Fishery Bulletin, 96, 271-284.

Kasparek, M., Godley, B.J. \& Broderick, A.C. (2001) Nesting of the green turtle, Chelonia mydas, in the Mediterranean: a review of status and conservation needs. Zoology in the Middle East, 24, 45-74.

Lebuff, C.R.J. (1990) The Loggerhead Turtle in the Eastern Gulf of Mexico. Caretta Research Inc., Sanibel, USA.

Limpus, C.J. \& Nicholls, N. (1988) The Southern Oscillation regulates the annual numbers of green turtle (Chelonia mydas) breeding around Northern Australia. Australian Journal for Wildlife Research, 15, 157-161. 
Miller, J.D. (1999) Determining clutch size and hatching success. In Research and Management Techniques for the Conservation of Sea Turtles (eds K.L. Eckert, K.A. Bjorndal, F.A. Abreu-Grobois \& M. Donnelly), pp.124-129. IUCN/SSC Marine Turtle Specialist Group Publication No. 4, Washington, DC, USA.

Mrosovsky, N. \& Provancha, J. (1992) Sex ratio of hatchling loggerhead sea turtles: data and estimates from a 5-year study. Canadian Journal of Zoology, 70, 530-538.

Murphy, T.M. and Hopkins, S.R. (1984) Aerial and Ground Surveys of Marine Turtle Nesting Beaches in the Southeast Region, United States. Final Report to National Marine Fisheries Service Contract No. NA83-GA-C-00021, Southeast Fisheries Center, Miami, USA

NMFS \& FWS (National Marine Fisheries Service \& Fish and Wildlife Service) (1991) Recovery Plan for the US Population of the Loggerhead Turtle Caretta caretta. Final Report to the National Marine Fisheries Service, Washington, DC, USA.

NMFS \& FWS (National Marine Fisheries Service \& Fish and Wildlife Service) (1995) Status Reviews for Sea Turtles Listed Under the Endangered Species Act of 1973 (ed. P.T. Plotkin), pp. 1-23. Silver Spring, Maryland, USA.

National Research Council (1990) Population trends. In Decline of the Sea Turtles: Causes and Prevention, pp. 42-50. National Academy Press, Washington, DC, USA.

Santos, A.S., Marcovaldi, M.A. \& Godfrey, M.H. (2000) Update on the nesting population of loggerhead sea turtles in Praia do Forte, Bahia, Brazil. Marine Turtle Newsletter, 89, 8-11.

Schroeder, B. and Murphy, S. (1999) Population surveys (ground and aerial) on nesting beaches. In Research and Management Techniques for the Conservation of Sea Turtles (eds K.L. Eckert, K.A. Bjorndal, F.A. Abreu-Grobois \& M. Donnelly), pp. 45-55. IUCN/Species Survival Commission Marine Turtle Specialist Group Publication No. 4, Washington, DC, USA.

Schroeder, B.A., Foley, A.M. \& Bagley, D.A. (2003) Nesting patterns, reproductive migrations, and adult foraging areas of loggerhead turtles. In Loggerhead Sea Turtles (eds A.B. Bolten \& B.E. Witherington), pp. 114-124. Smithsonian Books, Washington, DC, USA

Shoop, C.R., Ruckdeschel, C. \& Thompson, N.B. (1985) Sea turtles in the southeastern United States: nesting activity as derived from aerial and ground surveys, 1982. Herpetologica, $41,252-259$.

Snover, M.L. (2002) Estimation of age, detection of habitat shifts, and the implications of growth rate variability on population dynamics for loggerhead and Kemp's ridley sea turtles. PhD thesis, Duke University, North Carolina, USA.

Turtle Expert Working Group (1998) An Assessment of the Kemp's Ridley Sea Turtle (Lepidochelys kempii) and Loggerhead (Caretta caretta) Sea Turtle Populations in the Western North Atlantic. NOAA Technical Memorandum NMFS-SEFSC-409, Miami, USA.

Turtle Expert Working Group (2000) Assessment Update for the Kemp's Ridley and Loggerhead Sea Turtle Populations in the Western North Atlantic. NOAA Technical Memorandum NMFS-SEFSC-444, Miami, USA.

Turtle Island Restoration Network (2002) Petition to list the Northern and Florida panhandle subpopulations of the loggerhead sea turtle (Caretta caretta) as endangered species throughout their range in the western North Atlantic Ocean and designate critical habitat. Filed to The Office of Endangered Species, National Marine Fisheries Service, US Department of Commerce and US Fish and Wildlife Service, United States Department of the Interior, 10 January 2002.

Yntema, C.L. \& Mrosvosky, N. (1980) Sexual differentiation in hatchling loggerheads (Caretta caretta) incubated at different controlled temperatures. Herpetologica, 36, 33-36.

\section{Biographical sketches}

Lucy Hawkes is a graduate student with the Marine Turtle Research Group studying loggerhead turtles from the United States and the Republic of Cape Verde. Her research centres on nesting ecology, and post-nesting migratory movements and behaviour of loggerhead turtles.

Annette Broderick and Brendan Godley coordinate the international research of the Marine Turtle Research Group (http://www.seaturtle.org/mtrg) at a wide range of sites around the world including Ascension Island, Brazil, Guinea Bissau, Northern Cyprus, Turkey and the UK Overseas Territories in the Caribbean. They also edit the international Marine Turtle Newsletter (http:/ / www.seaturtle.org/mtn).

Matthew Godfrey is Coordinator for the North Carolina Sea Turtle Project and his extensive experience in research on and conservation of marine turtles includes fieldwork in Brazil, French Guiana, Suriname, Turkey and the USA. 